\title{
Industrial Cognitive Engineering
}

\section{Thomas Mühlbradt and Peter Kuhlang}

\begin{abstract}
The term "cognition" describes mental processes, such as perception, memory, thought, learning, and language. Independent, although interacting, developments contribute to the fact that the proportion of cognitive functions in industrial work systems is steadily increasing and that their contribution to value added is becoming more performance-defining. Companies across-the-board are not sufficiently prepared for changes of this kind. Consequently, there is a strong demand for reliable methods with the help of which all tasks related to cognitive functions and the resulting complexity of industrial value added can be mastered in a targetoriented way and on an appropriate industrial level. "Industrial Cognitive Engineering" meets both these requirements. It combines cognitive engineering with the approved practical approaches and experiences of industrial engineering. Furthermore, its integration into the framework of workplace innovation is discussed.
\end{abstract}

Keywords: Cognition, Industrial Cognitive Engineering, Industrial Work Systems, Value Added, Workplace Innovation 


\section{Cognitive Functions in Industrial Work Systems}

By "cognition" we mean mental processes, such as perception, memory, thought, learning, and language. Cognitive sciences, an interdisciplinary approach including psychology, neuro sciences and linguistics (Miller 2003), has been doing research work on cognition since the 1950s.

Man, potentially machines, and man-machine-systems (MMS) are "cognitive systems": "A cognitive system produces "intelligent action", that is, its behaviour is goal oriented, based on symbol manipulation and it uses knowledge of the world (heuristic knowledge) for guidance. Furthermore, a cognitive system is adaptive, and able to view a problem in more than one way. A cognitive system operates using knowledge about itself and the environment, in the sense that it is able to plan and modify its actions on the basis of that knowledge. It is thus not only data driven, but also concept driven. Man is obviously a cognitive system. Machines are potentially if not actually, cognitive systems. An MMS, regarded as a whole, is definitely a cognitive system.” (Hollnagel \& Woods 1983, p. 589).

The proportion of cognitive functions in industrial work systems is steadily increasing and their contribution to added value is continually becoming more performance-defining. Many independent, although interacting developments contribute to this:

- Progressing digitalization of processes and tools

- Complex interfaces in man-machine systems

- Down-shifting of tasks and responsibilities to the value-added level

- Consolidated performance due to focussing on value-adding processes

- Necessity for continuous improvement of work processes due to competition

- Local accumulation of knowledge and experiences in work systems

In other words: knowledge work is becoming a prevailing feature of ever more work systems. This applies to both direct and indirect areas (North \& Güldenberg 2008; Pfeiffer 2008). Companies in many sectors of the market are not sufficiently prepared for changes of this kind.

- Traditional approaches to maintain knowledge and competences are unsatisfactory (Staudt \& Kriegesmann 1999; Bauer, et al. 2010) and the chances for informal learning at work, as a source for innovations, are far from being exhausted (Garibaldo 2011; Hartmann \& Garibaldo 2011)

- Consolidated performance in combination with inappropriate work equipment and basic conditions, results in work-induced stress. Today, the negative implications on health caused by chronic stress are considered a blanket problem by experts (Lohmann-Haislah 2012; Morschhäuser et al. 2014) 
- Demographic change in the industrialised countries (Mühlbradt \& Schultetus 2004; Mühlbradt \& Grumbach 2005) often is beyond the companies' capabilities for generation management in sectors such as staff assignment, competence management, and knowledge transfer.

Consequently, there is a strong demand for approaches that focus on all tasks related to cognitive functions and the resulting complexity of industrial value added, and that can be applied, at the same time, on an appropriate industrial level. "Industrial Cognitive Engineering" meets both these requirements.

\section{Industrial Cognitive Engineering}

Bokrantz \& Landau (2012, p. 37) define industrial engineering as: “... selecting and applying adequate methods within productivity management, aiming at the preventive and consistent optimisation of productivity." Apart from being widely applied in industry, industrial engineering is also part of university programmes, such as ergonomics and industrial science. In addition, there are IE associations that develop and maintain the methods and offer certified vocational training and training across-the-board. At the same time, these technical associations, offering a variety of communication media and platforms, serve as "communities of practice" (Wenger 1998) for the industrial engineers in the companies. To this day, in practical industrial engineering the methods of industrial science dominate relevant courses and lectures, methods compilations, and educational offers.

There are certain features that characterise the application of industrial engineering in the field, such as:

- The design of practicable solutions in industrial daily work is highly target- and implementation-oriented.

- Stress is laid on objective, if possible quantitative data for the design and assessment of work systems, as well as, on the application of parameters for controlling and optimising work systems.

- The methods are widely applied in industry, accompanied by a community of practice.

- Methods compilations as condensation nuclei of technical competence, defined as standards, are passed on by specifically trained instructors in the community of practice, and are adapted to new requirements through the dialogue with the community.

- Establishing and securing the professional competence of industrial engineers by combining scientific basics, methods, practical experience, and the exchange of experiences. 
- Suitability as reference methods for the regulations in company and collective agreements.

It is against this background that the long-standing global success of industrial engineering has to be understood (Landau 2013). Today, the relevance of industrial engineering for innovations and competitiveness is acknowledged not only by industry and engineering sciences: „... the involvement of ... industrial organisations ... should be further increased and developed in all types of programmes, with particular regard to workplace-centred programmes. Among these intermediary organisations, those employing widely-accepted methods and standards of work design should receive special attention." (CEDEFOP ${ }^{1}$ 2012, p. 11).

Independent of Industrial engineering, various authors have invented the term "cognitive [systems] engineering" in the early 1980s. It is an interdisciplinary approach required by the increasing number of computers in the companies, and the disastrous failure of complex technical systems, as was the case in the Three Mile Island accident.

Cognitive engineering ,[is] ... a type of applied Cognitive Science, trying to apply what is known from science to the design and construction of machines“(Norman 1986, p. 31). Hollnagel \& Woods (1983) demand: "The design of properly functioning MMS requires a different kind of knowledge which describes the cognitive or mental functions of the MMS“ (loc. cit., p. 583). In the German-speaking countries, the term "engineering psychology", as a subfield of applied psychology, has been invented as early as the 1960s (Hacker 1986). In a very similar way, engineering psychology strives to integrate the knowledge of human features into technical systems. Initially the understanding of "cognitive engineering" was strongly linked to the design of the man-machine interaction; in the recent past, however, a more broadly based conception can be observed. Woods \& Roth write (2005, p. 62): "Cognitive engineering is about human behaviour in complex worlds."

Thus, in the given context, the object of study in "cognitive engineering" can be said to be work systems, the performance of which is based on high cognitive requirements. The cognitive requirements of the task, the usage of tools and devices, human interaction or a combination of such sources, result in a complexity that affects the experiencing and behaviour of the people involved. Cognitive engineering aims at analysing cognitive processes and structures within work systems, at designing them, if possible, prospectively, and at assessing them with the goal of achieving security, productivity and a complexity that is ideal for the well-being (Buffet et al. 2013) for all people involved.

For Industrial Cognitive Engineering (ICE), knowledge of cognition and complexity has to be interlinked with approved practical approaches and experiences made in industrial engineering. Typical fields of application of ICE are:

- Development and design of cognitive equipment

\footnotetext{
${ }^{1}$ CEDEFOP: European Centre for the Development of Vocational Training.
} 
- Human interaction combined with machine intelligence

- Company information and knowledge management

- Reduction of psychic strain at work

- Design of work systems that stimulate learning processes

- Intergenerational knowledge transfer within the company

In the sense of ICE, highly cognitive-oriented tasks revealing new contents may be successfully processed already today by means of the approved approaches of Industrial engineering, which focusses on realisation and methods. This is exemplarily illustrated in section 3 . Section 4 approaches open questions, focusing on discussing ICE against the background of Workplace Innovation. Finally, section 5 begins to consider strategies to establish a sufficient number of ICE-experts in industry. In addition to the engineers and technicians that have already been addressed via the existing Industrial Engineering Community, new target groups for ICE can be reached and trained to be competent actors.

\section{ICE Case Study "Intergenerational Knowledge Transfer"}

Accumulated (experience-based) knowledge may get lost when the knowledge-bearer leaves. This applies, for example, to technical tasks or such tasks that involve customer-contact. In general, companies do not avail of strategies or tools for the identification and transfer of knowledge when the job holder changes. Particularly with respect to "implicit knowledge" (Nonaka \& Takeuchi 1995) or "tacit knowledge" (Polanyi 1974) there is significant uncertainty concerning transferability. Knowledge transfer is performed implicitly or is improvised, which leads to unsatisfactory results. In case there is a demography-based round of retirement, i. e. if many employees retire within a short period of time, the companies' existing concepts and capacities are unable to cope with the resulting challenge.

In this case, it is beyond doubt that cognitive aspects, such as knowledge, knowledge structures, or visualisation and communication of knowledge, play a prominent role. The transition from old to new job holders represents a regular cognitive process within a work system. The question then is whether this process can be a subject-matter of ICE. For this the following preconditions should be met:

- A trainable and learnable method exists that can be applied irrespective of the person(s) involved.

- This method represents a standard that is expedient and efficient for the intended field of application.

- The method has been sufficiently tested in industrial practice.

- Professional competence results from the combination of basic knowledge, methods, and practical experience acquired in practical application. 
Such methods may be found in practical work: the example of a medium-sized family company will help to illustrate this. The company is a specialist in the development and production of heavy-duty tires, transport castors, and the corresponding system components. Even for complete chassis system components this company has entered into design partnerships with its customers. The company produces in Germany and locations abroad, and avails of a worldwide sales organisation. In Germany, there are approximately 300 employees. 80 percent of these are qualified technicians or clerical workers. The average age today is roughly 44 years and will rise to more than 50 in 2020 . For this reason, the company decided to develop a concept and to apply it as a standard in order to face the loss of knowledge when employees leave the company.

The method was designed to be used by a transfer attendant whose task it is to guide both the new and the old employee through the transfer process. The core elements of this method are:

- $\quad$ Preparation and transfer planning

- $\quad$ Modeling the leaving employee's knowledge structures

- $\quad$ Comparing them with the successor's current knowledge level

- $\quad$ Setting up a transfer plan, with contents, methods, and time schedule

- $\quad$ Systematic processing and documentation of the transfer

- Follow-up and assessment

The individual phases will be directly supported by specific instructions or patterns. Thus, the method creates a standardised process. At the beginning of the transfer process a knowledge map is drawn for the current job holder. The contents of this map is then compared with the knowledge of the successor. Based on the result of this comparison, all persons involved form a team and establish a written transfer plan, including all the relevant knowledge, intended procedures, and a transfer schedule. Figure 3 shows a transfer plan in part. 
Transfer Plan

Job Situation 4: Supply Engineering

\begin{tabular}{|c|c|c|c|}
\hline no. & & task & deadline \\
\hline 4.1 & \multicolumn{2}{|c|}{ document and update piping system } & $9-30-2006$ \\
\hline 4.2 & \multicolumn{2}{|l|}{ electricity } & $9-30-2006$ \\
\hline 4.3 & \multicolumn{2}{|l|}{ water } & $9-30-2006$ \\
\hline 4.4 & \multicolumn{2}{|c|}{ compressed air } & $9-30-2006$ \\
\hline no. & accompl. & documentation of task, comments & Sign. \\
\hline 4.1 & 8-31-2006 & all plans updated & \\
\hline 4.2 & $9-15-2006$ & all processes documented & \\
\hline 4.3 & $9-15-2006$ & all processes documented & \\
\hline 4.4 & 9-15-2006 & all processes discussed & \\
\hline \multicolumn{4}{|c|}{ Job Situation 4: Supply Engineering } \\
\hline no. & \multicolumn{3}{|c|}{ task } \\
\hline 4.1 & \multicolumn{3}{|c|}{ document and update piping system } \\
\hline \multicolumn{4}{|c|}{ learning content } \\
\hline \multicolumn{4}{|c|}{$\begin{array}{l}\text { GP means General plan exists } \\
\text { E means electric cable } \\
\text { W means pipes for fresh, used and rain water } \\
\text { FW means fire fighting water } \\
\text { CA means compressed air pipes } \\
\text { LS means letter shoot } \\
\text { LTC means low-tension current } \\
\text { GP means gas pipes }\end{array}$} \\
\hline
\end{tabular}

Figure 3: Transfer plan in part

The standard procedure can cover a limited amount of transfer knowledge only: methodical and time-related restrictions impose limits here. However, a reliable quota of 50 to $60 \%$ of otherwise lost knowledge is sufficient to compensate the effort undertaken. There will also be cases of knowledge transfer for which the drafted methodical standards will not work. This may be the case, for example, if no temporal overlapping of the positions of predecessor and successor is possible. However, this is no substantial argument against the described approach, as in wide ranges of industry, it is necessary to perform a multitude of comparable tasks in adequate quality and at reasonable costs.

The presented example does not focus on profound and up-to-date findings related to human thought and knowledge structures, but rather on appropriate professional competence (cf. Dehnbostel 2010) resulting from a combination of technical knowledge, methodical routine, and practical experience. The required technical knowledge is limited and may definitely be imparted in condensed form. This distinguishes the described method from more scientificallyoriented approaches that cause significantly more costs, while providing mostly vague additional value (e.g. Irle 2008). Competence gain and methodical advancement do not require elaborate new theories in cognitive science, but rather ask for a vivid community of practice (Wenger 1998) that promotes an exchange of practical experiences and is jointly involved in securing and developing methods and qualification standards. 


\section{ICE in relation to Workplace Innovation}

Research and development related to ICE will deal with the identification and editing of existing experiences on the one hand, and with the independent development and testing of new methods on the other hand. Existing and new methods are then collected into methods compilations that provide the basis for qualification measures. Apart from the described example of knowledge transfer, there are already approaches that promise to be suitable as future methodical standards. These include approaches in the fields of knowledge management (Mühlbradt 2007; 2008; Bohlander et al. 2011), demography management (Ruf \& Mühlbradt 2013), and optimisation of load (Richter \& Schütte 2013). Further methods will have to be established and tested in research and development projects. Applied research of this kind is currently being performed, for example, as part of the BMBF project "Engineering und Mainstreaming lernförderlicher industrieller Arbeitssysteme für die Industrie 4.0 (ELIAS)" ${ }^{\prime 2}$. Approved, efficient and appropriate methods for the identification and processing of job characteristics relevant for learning are already available for short-cycle routine jobs (e.g. Liker \& Meier 2008). However, this cannot be claimed to be true for more complex jobs. For these jobs it is necessary to develop adequate methods and test them in an industrial environment, in order to systematically enlarge both the methodology and the range of ICE. Other sections of ICE require further advancement, for example the man-machine-interaction with respect to so-called "intelligent assistance systems" (Forschungsunion 2012).

In a wider research perspective, it has to be acknowledged that ICE is a necessary but not a sufficient condition for the design of future workplaces. Its cognitive perspective is vital in a world of digitisation but is fails to directly address questions of leadership (Dombrowski \& Mielke 2014), learning culture (Mühlbradt et al. 2015) or work organization (Mühlbradt et al. in press). Therefore, it remains unclear how ICE is to be integrated in socio-technical systemdesign. This deficit can be overcome by considering the role of ICE within the context of Workplace Innovation.

For some time now, the term 'Workplace Innovation' has been discussed in academic literature (e.g. Applebaum et al 2010; Pot 2011; Oeij et al. 2012; Eeckelaert et al 2012; Totterdill 2015). Pot $(2011$, p. 1) defines Workplace Innovation as "...new and combined interventions in work organisation, human resource management and supportive technologies". Totterdill (2015, p. 57) writes: "Workplace Innovation seeks to build bridges between the strategic knowledge of the leadership, the professional and tacit knowledge of frontline employees, and the organisational design knowledge of experts." Dhondt \& Hootegem (2015, p. 18) make an explicit connection to the digitisation of work, and see Workplace Innovation as an important design perspective. According to Totterdill, Dhondt \& Milsome (2002), Workplace Innovation aims at improving the company's capacity for innovation and competitiveness while enhancing the quality of working life.

\footnotetext{
2 Funded by BMBF on the basis of a decision by Deutscher Bundestag (German Federal Parliament), reference number 01XZ13001; www.projekt-elias.de
} 
Totterdill (2015 p. 64) proposes a conceptual model of Workplace Innovation. This model comprises a considerable percentage of elements which have a strong relationship to the cognitive perspective and methods of ICE:

- Integration of technology

- Learning and development

- Shared knowledge and experience

- Integrating tacit and strategic knowledge

In order to treat these topics appropriately in an industrial context, it is necessary to apply specific knowledge and methods from ICE, and to utilise the competencies of ICE-experts. However, ICE-experts need to be able to understand their tasks as a contribution to a broader endeavour. This raises questions concerning training and recruitment, which will be addressed in the final section.

\section{Establishing ICE-professionals}

The innovative field of ICE combines industrial engineering and cognitive engineering. It provides practicable methods and industrial-scale competence, and serves the advancement of the methods within a community of practice. The theories and methods of cognitive engineering originate to a considerable extent from psychology. Apart from the fields of general and biological psychology, the application fields of work and organisational psychology or engineering psychology have to be mentioned. This perspective is interesting also with respect to the number of graduates. The number of graduates from this branch of university studies has increased significantly and steadily over the last decades. This development at universities has been paralleled for some time by a renaissance of 'Wirtschaftspsychologie' (Business Psychology, a phrase strongly connected to the German psychologist Hugo Münsterberg) at universities of applied sciences. Therefore, work and organisational, engineering and industrial psychologists may very well form a considerable part of future ICE-professionals. The focus on targets and their achievement, characteristic of industrial engineering, perfectly fits into the classical self-conception of Business Psychology: "Münsterberg took the view that science should serve the solution of practical problems, or even more, that science only justified itself by its practical utility." (Kanning et al. 2007, p. 238) ${ }^{3}$. Moreover, Business Psychology matches well with those elements of the conceptual model of Totterdill (2015) not directly addressed by ICE.

ICE as an interdisciplinary field may also contribute to improve on certain persistent problems of applied psychology. Despite the Bologna Reform, there still are complaints as to the lack of practical relevance of work and organisational psychology (von Rosenstiel 2004, 2005;

3 For the academic-theoretical basis of such an application-oriented psychology see Hartmann (2005). 
Kanning et al. 2007), and persistent problems in the relationship between theory and practice are stated: "Practitioners and students of psychology are left alone with questions of transformation of scientific results into practice. The study and the reflection of the relationship between theory and practice fall back to a level discussed 40 year ago" (Bergold 2008, p. 1). In programmes related to industrial psychology, the practical relevance is probably stronger, and the stress ratio between theory and practice weaker: however, at present these programmes definitely focus on topics of market and marketing psychology or organisational and personal psychology, rather than on contents related to work and engineering psychology (e. g. Brandenburg \& Thielsch 2009).

In particular, industrial engineering associations with a close link to industry may assume an integrating and advancing function here, as work and organisational psychology seems to be ideally integrated into an engineering environment: "Work and engineering institutes in particular, are obviously well-suited to be home to the priority setting of work and organisational psychology in research and teaching." (von Rosenstiel 2004, p. 92).

\author{
About the Authors \\ Dr. rer. pol. Dipl.-Psych. Thomas Mühlbradt, Head of Research, MTM Institute \\ Professor Dr. Peter Kuhlang, Head, MTM Institute \\ Deutsche MTM-Vereinigung e.V. (German MTM Association), Hamburg and Aachen \\ Emails: Thomas.Mühlbradt@dmtm.com peter.kuhlang@dmtm.com
}

\title{
References
}

Appelbaum E., Gittell J., \& Leana C. (2010). High performance work practices and sustainable economic growth. CEPR Centre for Economic Policy Research.

Bauer A., Korge A., Korge G., \& Reiner D. (2010). Wettbewerbsfähigkeit durch Lernen. (Arbeitgeberverband Gesamtmetall (federation of German employers' associations in the metal and electrical engineering ( $M+E)$ industries), Ed.). Köln: IW Medien Köln.

Bergold J. B. (2008). “Zurück in den Elfenbeinturm! Psychologiestudium ohne Praxis?“ Journal für Psychologie, 16(1), 1-19.

Bohlander H., Mühlbradt T. \& Kivikas M. (2011): Ressource Wissen nutzen: Wissensmanagement strategieorientiert entwickeln. Bertelsmann, Bielefeld.

Bokrantz R., \& Landau K. (2012). Handbuch Industrial Engineering: Produktivitätsmanagement mit MTM. Stuttgart: Schäffer-Poeschel. 
Brandenburg T., \& Thielsch M. (Eds.). (2009). Praxis der Wirtschaftspsychologie. Münster: MV-Wissenschaft.

Buffet M.-A., Gervais R., Liddle M., \& Eeckelaert L. (2013). Well-being at work : creating a positive work environment. Luxembourg: European Agency for Safety and Health at Work.

CEDEFOP (2012). Learning and innovation in enterprises. Luxembourg: Publications Office of the European Union.

Dehnbostel P. (2010). Betriebliche Bildungsarbeit. Schneider Verlag Hohengehren.

Dhondt S. \& Hootegem G. Van (2015). "Reshaping workplaces: workplace innovation as designed by scientists and practitioners". European Journal of Workplace Innovation 1.1. pp. $17-24$.

Dombrowski U. \& Mielke T.: "Lean Leadership - 15 Rules for a Sustainable Lean Implementation.” In: Procedia CIRP. Elsevier B.V., 2014. pp. 565-570.

Forschungsunion. (2012). Umsetzungsempfehlungen für das Zukunftsprojekt Industrie 4.0. Download von: http://www.forschungsunion.de/

Eeckelaert L. et al. (2012). Review of workplace innovation and its relation with occupational safety and health. European Agency for Safety and Health at Work. Luxembourg.

Garibaldo F. (2011). "A Human-Centered Design for Work Places: Opportunities and Constraints.” In Jeschke S., Isenhardt I., Hees F., \& Trantow S. (Eds.), Enabling Innovation: Innovative Capability - German and International Views. Berlin: Springer.

Hacker W. (1986): Allgemeine Arbeits- und Ingenieurpsychologie: Verlag Hans Huber.

Hartmann E. A. (2005). Arbeitssysteme und Arbeitsprozesse. Schriftenreihe MTO, Band 38. Zürich: Vdf Hochschulverlag AG.

Hartmann E. A., \& Garibaldo F. (2011). "What's going on out there? Designing work systems for learning in real life". In Jeschke S., Isenhardt I., Hees F., \& Trantow S. (Eds.), Enabling Innovation: Innovative Capability - German and International Views.

Hollnagel E. (1983). “Cognitive Systems Engineering: New wine in new bottles”. International Journal of Man-Machine Studies, 18(6), 583-600.

Irle M. (2008). Erkenntnisse aus der Fieberkurve. Band Eins, 166-173.

Kanning U. P., et al. (2007). "Angewandte Psychologie im Spannungsfeld zwischen Grundlagenforschung und Praxis - Plädoyer für mehr Pluralismus“. Psychologische Rundschau, 58(4), 238-248.

Landau K. (2013). “Mehr Tun Müssen?“ 100 Jahre Produktivitätsmanagement. Ergonomia.

Liker J. K., \& Meier D. P. (2007). Toyota Talent. New York: McGraw-Hill. 
Lohmann-Haislah A. (2012). Stressreport Deutschland 2012. Bundesanstalt für Arbeitsschutz und Arbeitsmedizin (German Federal Institute for Occupational Safety and Health) (Ed.). Dortmund/Berlin/Dresden.

Miller G. (2003). The cognitive revolution: a historical perspective. Trends in Cognitive Sciences, 7(3), 141-144.

Morschhäuser M., Beck D., \& Lohmann-Haislah A. (2014). "Psychische Belastung als Gegenstand der Gefährdungsbeurteilung“. In Bundesanstalt für Arbeitsschutz und Arbeitsmedizin (German Federal Institute for Occupational Safety and Health) (Ed.), Gefährdungsbeurteilung psychischer Belastung (pp. 19-44). Berlin: Erich Schmidt Verlag.

Mühlbradt T., \& Grumbach J. (2005). "Arbeit und Innovation im demografischen Wandel“". ARBEIT. Zeitschrift Für Arbeitsforschung, Arbeitsgestaltung Und Arbeitspolitik, (4), 359-363.

Mühlbradt T., Kuhlang P. \& Finsterbusch T. (in press). "Lernförderliche Arbeitsorganisation für die Industrie 4.0“. In: Institut für Innovation und Technik (Ed.): Begleitforschung Autonomik. Band 2. Berlin.

Mühlbradt T., Kuhlang P. \& Senderek R. (2015). "Lernkultur als Kernkompetenz: Das arbeitsnahe Lernen in der Industrie 4.0. In: ABWF Bulletin. 2015. pp. 23-30.

Mühlbradt T. \& Schultetus W. (2004): “Auswirkungen des demografischen Wandels Strategien mit betrieblichen demografischen Analysen“. Zeitschrift für angewandte Arbeitswissenschaft, Nr. 179, pp. 1-16.

Nonaka I., \& Takeuchi H. (1995). The Knowledge-Creating Company: How Japanese Companies Create the Dynamics of Innovation. Oxford University Press, USA.

Norman D. A. (1986). “Cognitive Engineering”. In Norman D.A. \& Draper S.W. (Eds.), User Centered System Design; New Perspectives on Human-Computer Interaction (pp. 31-61). Hillsdale, NJ, USA: L. Erlbaum Associates Inc.

North K., \& Güldenberg S. (2008). Produktive Wissensarbeiter. Wiesbaden: Gabler.

Oeij P. et al. (2012). "Workplace Innovation and its Relations with Organisational Performance and Employee Commitment". LLinE, 4.

Pfeiffer S. (2008). "Montage, Wissen und Erfahrung". In Lang C., Pfeiffe S.R, \& Adami F.R.W.(Eds.), Montage braucht Erfahrung: Erfahrungsbasierte Wissensarbeit in der Montage (pp. 14-48). Hampp, Rainer.

Polanyi M. (1974). Personal Knowledge: Towards a Post-Critical Philosophy. University of Chicago Press.

Pot F. D. (2011). "Workplace innovation for better jobs and performance". International Journal of Productivity and Performance Management, 60 (4). 404-415. 
Richter G., \& Schütte M. (2014). "Portraits exemplarisch ausgewählter Analyseinstrumente“. In Bundesanstalt für Arbeitsschutz und Arbeitsmedizin (German Federal Institute for Occupational Safety and Health) (Ed.), Gefährdungsbeurteilung psychischer Belastung: Erfahrungen und Empfehlungen (pp. 187-264). Berlin: Erich Schmidt Verlag.

von Rosenstiel L. (2004). "Arbeits- und Organisationspsychologie - Wo bleibt der Anwendungsbezug?" Zeitschrift Für Arbeits- Und Organisationspsychologie A\&O, 48(2), 8794.

von Rosenstiel L. (2005). Anmerkungen zu "Vom Ansehen der Arbeits- und Organisationspsychologie: Ein Kommentar zu von Rosenstiel (2004)“ König v.C.J und Melchers K.G. Zeitschrift Für Arbeits- und Organisationspsychologie A\&O, 49(2), 105-106.

Ruf U.-P. \& Mühlbradt T. (2013):“Den Demographischen Wandel gestalten: Vom Werkzeugkasten zur betriebsindividuellen Lösung". In: AmCham Germany und F.A.Z.-Institut (Ed.), Demographischer Wandel - Zukunft verantwortungsvoll gestalten. Frankfurt, pp. 42-47.

Staudt E., \& Kriegesmann B. (1999). "Weiterbildung: Ein Mythos zerbricht.“ (E. Staudt, Ed.) Berichte aus der angewandten Innovationsforschung, Nr. 178. Bochum.

Totterdill P. (2015). "Closing the Gap: The Fifth Element and Workplace Innovation". European Journal of Workplace Innovation 1.1 , 55-74.

Totterdill P., Dhondt S. and Milsome S. (2002). Partners at work? A report to Europe's policy makers and social partners. Nottingham: The Work Institute. Available at

http://www.ukwon.net/files/kdb/0415f02fe854733c3d8e650791297cb0.pdf

Wenger E. (1998). Communities of Practice: Learning, Meaning, and Identity. Cambridge University Press.

Woods D. D., \& Roth E. M. (2005). “Cognitive Systems Engineering.” In Moray N. (Ed.), Ergonomics Major Writings Volume 1: The History and Scope of Human Factors. 